\title{
Companion to Central and Eastern European Humanism. Volume 2: The Czech Lands. Part 1: A-L.
}

Ed. Lucie Storchová. Berlin - Boston: De Gruyter. 2020. XVI + $782 \mathrm{~s}$.

ISBN 978-3-11-064642-9

Před časem jsme v tomto časopise stručně, zato naléhavě upozornili na knihu, po našem soudu důležitou, pojednávající o českých biblických překladech 16. století (srov. Linguistica Brunensia 66 (1), 2018, s. 105). Nyní chceme stejně stručně a naléhavě upozornit na první díl podobně důležité nebo alespoň podobně užitečné slovníkové příručky o humanistických spisovatelích - dobové „jazykovědce“ v to čítajíc - v českých zemích 16. století.

Předesláno je několik narativních textů. Nejdřív je to stručný úvod (Lucie Storchová: Introduction and Acknowledgments; s. VII-X), v němž se píše zejména o výběru položek do slovníku: jde o autory dlouhého 16. století (od poslední třetiny 15. do třicátých let 17. století) pracující tak či onak se „starými texty“ (scil. antickými texty) a narozené nebo působící v českých zemích. Tři studie pak pojednávají o literatuře v českých zemích v 16. století zejména co do recepce humanismu: nejdřív v první polovině 16. století (Petr Voit: Humanism in the Czech Lands in the First Half of the $16^{\text {th }}$ Century: Utraquists, Catholics and Non-Conformist Religious Communities; s. 1-22), pak v třetí čtvrtině 16. století (Lucie Storchová: Humanist Literature in the Czech Lands (from the 1550 s until the Late 1580s); s. 23-40) a nakonec od konce 16. do dvacátých let 17. století (Jan Malura, Lucie Vaculínová: The Literature of Late Humanism (from the 1590s until the Early 1620s); s. 41-59). Slovník pak obsahuje personální hesla různě dlouhá a různě podrobná (někdy až velmi dlouhá a podrobná) - podle významu portrétované postavy i názoru autora hesla o ní.

V úvodních textech je občas trocha „revizionismu“ jako „the nationalist history of literature“ (s. VII; navrhujeme autorce ke zvážení, zda by se místo „the Czech Lands“ nemělo nenacionalisticky užívat „the Bohemian Lands“) nebo jaksi hloubkově marxistická povaha české literární seziemistiky 2. poloviny 20. století (s. 8-12; myslím, že marxistická byla spíš povrchově nebo frazeologicky, skutečně byla „vernakularizující“, tj. měla za hodnotovou osu literárního dění vernakularizaci, navazující na předchozí vývoj a vedoucí k novodobému jazykovému národu, což ostatně nezáměrně postihuje sám autor, když navrhuje pro jev tzv. národního humanismu, onou seziemistikou vyzdvihovaného, užívat termín protoobrození, srov. k tomu VYкYPĚL 2019). Přirozeně by se také tu a tam mohlo něco doplnit (například jazykovědec by jistě k Nudozerinovi doplnil Koupila 2015, 47 a k Veleslavínovi Koupila 2018, 2019). Ale celkově není pochyb, že př́ručka představuje cennou pomůcku, pro svůj anglický háv pak zvláště pro nebohemistické publikum.

\section{LITERATURA}

KoupIL, Ondřej. 2015. Grammatyka cžeska. Mluvnice češtiny v 16. až 19. století (katalog výstavy). Praha: Akropolis. 
KoupIL, Ondřej. 2018. Veleslavínská čeština a veleslavínská doba. Česká literatura 66, 263-280.

KoupiL, Ondřej. 2019. Veleslavínův „trojjazyčný“ nomenklátor a komprimace/dilatace v českém pravopisu raného novověku. Listy filologické 142, 49-84.

VyKYPĚL, Bohumil. 2019. Obrození a vernakularizace. In: MALČík, Petr - KarLík, Petr, eds. Svět podle Grepla. Prof. Miroslavu Greplovi k devadesátým narozeninám. Brno: Host, 205-208.

Bohumil Vykypèl

Czech Language Institute of the CAS, v. v. i.

Veveř́ 97,602 oo Brno

Czech Republic

vykypel@ujc.cas.cz 